\title{
ENHANCEMENT OF STUDENTS' MATHEMATICAL COMMUNICATION UNDER METACOGNITIVE SCAFFOLDING APPROACH
}

\author{
Sufyani Prabawanto \\ Universitas Pendidikan Indonesia
}

\begin{tabular}{l} 
Article Info \\
\hline Article history: \\
Received July 15, 2019 \\
Revised July 30, 2019 \\
Accepted Sept 27, 2019 \\
\hline
\end{tabular}

Keywords:

Mathematical Communication, Metacognitive Approach.

\begin{abstract}
This research aims to investigate the enhancement of students' mathematical communication under metacognitive scaffolding approach. This research used a quasi-experimental design with pretest-posttest control. The subjects were pre-service elementary school teachers in Bandung. In this study, there were two groups of subjects: experimental and control groups. The experimental group consists of 60 students under metacognitive scaffolding approach, while the control group consists of 58 students under direct approach. Based on the prior mathematical ability, the students were classified into three levels, namely high, midlle, and low. Data collection instrument used mathematical communication test. The conclusions of the research are: (1) there is a significant difference in enhancing mathematical communication ability between students who attended the course under metacognitive scaffolding approach and those under direct approach, and (2) there was no significant interaction effect between teaching approaches and ability levels based on prior knowledge in enhancing students' mathematical communication.
\end{abstract}

Copyright @ 2019 IKIP Siliwangi. All rights reserved.

\section{Corresponding Author:}

Sufyani Prabawanto,

Department of Mathematics Education,

Universitas Pendidikan Indonesia,

J1. Dr. Setiabudi No.229, Bandung, West Java 40154, Indonesia

Email: sufyani@upi.edu

\section{How to Cite:}

Prabawanto, S. (2019). Enhancement of students' mathematical communication under metacognitive scaffolding approach. Infinity, 8(2), 117-128.

\section{INTRODUCTION}

Mathematical communication is an important part of learning mathematics. It is explicitly stated in Regulation of National Education Minister of Republic of Indonesia Number 22 (Departemen Pendidikan Nasional RI, 2006). However, some of the survey results (Mullis et al., 2004, OECD, 2005, 2007, 2010) showed that Indonesian students' mathematical communication ability were quite low compared to some other countries. If it was seen from the content of mathematics in the surveys, a lot of the topics had been studied by the students while they were in elementary school. Thus the students' lack of mathematical communication was related to lack of their mathematical communication in elementary school. 
Elementary students' mathematical ability related to the teachers' ability. This linkage revealed in study reports. In their study report, Hill, Rowan, \& Ball (2005) stated that the mathematical ability of elementary school teachers was significantly related to students' mathematical achievement. Passos (2009) reported that there was a relationship between elementary school teacher competence and student achievement in reading and math. Therefore, it could be said that the development of mathematical communication of preservice elementary school teachers is very important. One effort to develop their mathematical communication ability was looking for factors expected to enhance their mathematical communication ability. One of the factors was a teaching approach.

Carpenter \& Gorg (2000) recommended an approach, namely metacognitive that includes strategy, planning, monitoring, and evaluation during the learning process. Although the approach had been recommended by experts, this approach still has drawbacks, such as when a student realized that he/she did not find a way to solved mathematical problems, he/she would pause in his own confusion. Yee (2002) reported that the metacognitive approach (without scaffolding) was not able to raise students' success in learning mathematics. Instead, Peters (2011) revealed that if the scaffolding approach run itself (not involving metacognitive) the students were weak in developing their own ways to solve problems. To overcome this, metacognitive approach needs to be combined with scaffolding.

For learning in the classroom that involves a lot of students, usually more than 30 people, metacognitive scaffolding approach was almost impossible to be implemented. Therefore, this approach needed to be combined with cooperative learning. In cooperative learning, the lower mathematical ability students could learn of mathematical work habits of higher mathematical ability students, and in the process of explaining the material, the higher mathematical ability students could develop mastery stronger and deeper understanding for themselves about the mathematical tasks. However, cooperative learning was not entirely a positive impact on students' academic performance (Hecox, 2010; Iqbal, 2004). Iqbal (2004) reported that low ability students of middle school at Rawalpindi got a benefit from cooperative learning, while high ability students did not have it, although they remain in position at the top in math achievement. Hecox (2010) found no difference in scores Florida Comprehensive Assessment Test (FCAT) among fourth-grade students who obtained teaching under cooperative learning and students who obtained traditional teaching in Polk County, Florida. Thus, metacognitive scaffolding approach in cooperative learning pattern was expected to enhance the students' mathematical communication ability.

Despite many studies that examine the influence of metacognitive approach, scaffolding or cooperative learning to academic performance in certain educational levels, but it did not found studies that aimed to review the enhancementof mathematical communication on low, middle and high ability students under metacognitive scaffolding approach in cooperative learning pattern, hereinafter referred to as metacognitive scaffolding approach. Thus, the purpose of this study was to find the students' mathematical communication after obtaining metacognitive scaffolding approach.

The research questions were, "Is there a difference of enhancement of mathematical communication ability between students who acquire teaching under metacognitive scaffolding approach and students who acquire teaching under direct approach?" and "Is there an interaction effect between teaching approaches (metacognitive scaffolding approach and direct approach) and students' prior mathematical ability (high, middle, and low) to the enhancement of mathematical communication ability?" To address that question, enhancement of mathematical communication of students taught by metacognitive scaffolding approach compared with that of a control group. Besides that, 
the enhancement both of students taught by metacognitive scaffolding approach and that of a control group based on the prior mathematical ability compared each others. In this study, the hypotheses were, "There is a difference of enhancement of mathematical communication ability between students who acquire teaching under metacognitive scaffolding approach and students who acquire teaching under direct approach" and "There is an interaction effect between teaching approaches and students' prior mathematical abilities toward enhancement of mathematical communication ability".

In this study, mathematical communication was considered as students' ability to understand and state mathematical ideas both in writing, and drawing. The indicators used in this study were: (1) stating a picture or diagram into mathematical ideas, (2) stating a daily occurrence in the mathematical symbols, and (3) explaining the idea, situation, or a mathematical relation with graphs or algebraic. Metacognitive scaffolding approach was considered as a teaching approach that was characterized by activities: (1) teacher raised a mathematical problem, (2) students tried to solve the problem; and (3) teacher provided temporary metacognitive assistance, which is gradually reduced and eventually the student can independently take full responsibility for mathematical tasks that must be completed; whereas direct approach, was consider as a teaching approach that was characterized by activities: (1) explanation or manipulation concept by teacher, (2) providing an opportunity for students to ask, (3) demonstrating completion of example problems, (4) giving exercises to be completed by the students, (5) asking some students to write again their answer on the board, (6) commenting on student answers, and (7) providing homework assignments if it deemed necessary.

\section{METHOD}

\subsection{Research Design}

The method used in this study was aquasi-experimental method. There were two groups of students. As the experimental group was students who acquire teaching mathematics under metacognitive scaffolding approach, while the control group were students who acquire teaching mathematics under direct approach. This study implemented a pretest and posttest for both groups of students. Thus the research design was the design of the control group pretest-posttest, and expressed as follows.

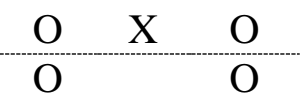

Description:

$\mathrm{O}$ : pretest-Posttest onmathematical communication.

$\mathrm{X}$ : Treatment in the form of learning with metacognitive scaffolding approach.

The research design involved two factors, namely learning approaches and student groups based on factors prior mathematical abilities. The first factor consisted of metacognitive scaffolding and direct approaches. The second factor consisted of a group of students based on prior mathematical ability (high, middle, and low). This research design could be described as the relationship between the factors as presented in Table 1 . 
Table 1. Average of Mathematical Communication Gain Based on Teaching Approach and Prior Mathematical Ability

\begin{tabular}{ccc}
\hline & \multicolumn{2}{c}{ Teaching Approach } \\
\cline { 2 - 3 } Prior Mathematical Ability & $\begin{array}{c}\text { Metacognitive } \\
\text { Scaffolding } \\
\text { Approach }\left(\mathbf{B}_{1}\right)\end{array}$ & $\begin{array}{c}\text { Direct Approach } \\
\left(\mathbf{B}_{2}\right)\end{array}$ \\
\hline High $\left(\mathrm{A}_{1}\right)$ & $\mathrm{A}_{1} \mathrm{~B}_{1}$ & $\mathrm{~A}_{1} \mathrm{~B}_{2}$ \\
Middle $\left(\mathrm{A}_{2}\right)$ & $\mathrm{A}_{2} \mathrm{~B}_{1}$ & $\mathrm{~A}_{2} \mathrm{~B}_{2}$ \\
Low $\left(\mathrm{A}_{3}\right)$ & $\mathrm{A}_{3} \mathrm{~B}_{1}$ & $\mathrm{~A}_{3} \mathrm{~B}_{2}$ \\
\hline
\end{tabular}

\subsection{Sample}

The research was conducted at the Elementary School Teacher Education Program at a university in Bandung. Thus, population of the study was all students of Elementary School Teacher Education Program who received mathematics education course, at a university in Bandung. Whereas the sample was 118 students; 60 students as an experiment groupand 58 students as a control group.

\subsection{Research Procedure}

Research activities initiated by determining the study sample. After the sample was set, each student was given a prior mathematical ability test. The test is intended to classify students based on prior mathematical abilities (high, midlle, and low). After the experimental and the control groups were formed, the students were given the pretest about the mathematical communication ability. After providing a treatment, posttest on mathematical communication was given for the students. For data analysis, researchers used the help of Statistical Package for Social Science (SPSS) for Windows version 20 software.

\subsection{Data Analysis}

There were two main hypotheses to be tested. The first one was related to test two independent samples with the interval ratio of measurement. The data was analyzed by $t$ test, 't' test, and Mann-Whitney. In the second hypothesis, data could be tested using twoways ANOVA if the conditions were available. If the conditions were not available, the interaction effect would be seen by the diagram and one way ANOVA or Kruskal-Wallis.

\section{RESULTS AND DISCUSSION}

\subsection{Results}

Descriptive statistical analysis of the results of students' mathematical communication ability was presented in Table 2. 
Table 2. DescriptionStatisticsof Students ‘ Mathematical communicationAbility (MCA)

\begin{tabular}{lccccccc}
\hline \multirow{2}{*}{ Group } & \multirow{2}{*}{ Level } & \multicolumn{2}{c}{ Pretest } & \multicolumn{2}{c}{ Posttest } & \multicolumn{2}{c}{ Gain of MCA } \\
\cline { 3 - 8 } & & Mean & SD & Mean & SD & Mean & SD \\
\hline \multirow{4}{*}{ Experiment } & Mix & 25.83 & 13.57 & 50.17 & 14.98 & 24.33 & 10.95 \\
& Low & 18.61 & 7.63 & 45.56 & 11.36 & 26.94 & 12.85 \\
& Middle & 24.40 & 12.10 & 47.60 & 15.22 & 23.20 & 8.40 \\
& High & 35.59 & 15.30 & 58.82 & 15.16 & 23.24 & 12.24 \\
\hline \multirow{3}{*}{ Control } & Mix & 33.71 & 9.49 & 46.98 & 11.28 & 13.28 & 7.75 \\
& Low & 29.21 & 7.50 & 43.68 & 11.28 & 14.47 & 9.11 \\
& Middle & 31.04 & 7.37 & 44.79 & 9.15 & 13.75 & 6.30 \\
& High & 42.81 & 8.16 & 53.75 & 11.62 & 10.94 & 7.79 \\
\hline
\end{tabular}

Ideal Maximum Score $(\mathrm{IMS})=100$.

From the Table 2, it was appeared that the enhancement of communication ability that students acquire teaching under metacognitive scaffolding approach was relatively higher than students who acquire teaching under direct approach, the well-viewed as a whole and viewed based on the level of prior mathematical ability. Inferential statistical analysis of the results of students' mathematical communication ability to experimental and control groups were presented in Table 3.

Table 3. Difference of Students' Mathematical Communications Ability (MCA)

Between Experiment and Control Groups

(The level of significance $\alpha=0.05$ )

\begin{tabular}{|c|c|c|c|c|}
\hline \multirow{2}{*}{ Variable } & \multirow{2}{*}{ Group } & \multicolumn{3}{|c|}{ Difference Test } \\
\hline & & Test Statistic & Sig. & Conclusion \\
\hline \multirow{2}{*}{$\begin{array}{c}\text { MCA-1 (Pretest) } \\
\text { Mix }\end{array}$} & Experiment & \multirow{2}{*}{ M-W test } & \multirow{2}{*}{0.000} & \multirow{2}{*}{ Different } \\
\hline & Control & & & \\
\hline \multirow{2}{*}{$\begin{array}{c}\text { Gain of MCA } \\
\text { Mix }\end{array}$} & Experiment & \multirow{2}{*}{ M-W test } & \multirow{2}{*}{0.000} & \multirow{2}{*}{ Different } \\
\hline & Control & & & \\
\hline \multirow{2}{*}{$\begin{array}{c}\text { MCA-1 (Pretest) } \\
\text { Low Ability }\end{array}$} & Experiment & \multirow{2}{*}{ t-test } & \multirow{2}{*}{0.000} & \multirow{2}{*}{ Different } \\
\hline & Control & & & \\
\hline \multirow{2}{*}{$\begin{array}{l}\text { Gain of MCA } \\
\text { Low Ability }\end{array}$} & Experiment & \multirow{2}{*}{ t-test } & \multirow{2}{*}{0.002} & \multirow{2}{*}{ Different } \\
\hline & Control & & & \\
\hline \multirow{2}{*}{$\begin{array}{l}\text { MCA-1 (Pretest) } \\
\text { Middle Ability }\end{array}$} & Experiment & \multirow{2}{*}{$\mathrm{M}-\mathrm{W}$ test } & \multirow{2}{*}{0.017} & \multirow{2}{*}{ Different } \\
\hline & Control & & & \\
\hline \multirow{2}{*}{$\begin{array}{l}\text { Gain of MCA } \\
\text { Middle Ability }\end{array}$} & Experiment & \multirow{2}{*}{ M-W test } & \multirow{2}{*}{0.000} & \multirow{2}{*}{ Different } \\
\hline & Control & & & \\
\hline \multirow{2}{*}{$\begin{array}{c}\text { MCA-1 (Pretest) } \\
\text { High Ability }\end{array}$} & Experiment & \multirow{2}{*}{$t^{\prime}$-test } & \multirow{2}{*}{0.100} & Not \\
\hline & Control & & & Different \\
\hline \multirow{2}{*}{$\begin{array}{c}\text { MCA-2 (Posttest) } \\
\text { High Ability }\end{array}$} & Experiment & \multirow{2}{*}{ t-test } & \multirow{2}{*}{0.291} & \multirow{2}{*}{$\begin{array}{c}\text { Not } \\
\text { Different }\end{array}$} \\
\hline & Control & & & \\
\hline
\end{tabular}

From the Table 3, it could be stated that there was difference in enhancing of mathematical communication ability significantly between students who attained teaching under metacognitive scaffolding approach (experimental group) and students who attained teaching under direct approach (control group), the well-viewed as a whole (mix) and 
viewed based on the prior mathematical ability levels (low and middle). If these results were associated with the results in Table 2 it can be concluded that the enhancement of students' mathematical communication who attained teaching under metacognitive scaffolding approach were higher than students who attained teaching under direct instructional approach.

The interaction effect between teaching approaches and prior mathematical ability toward enhancement of students' mathematical communication ability would be tested by using Two Ways ANOVA. Before using the Two Ways ANOVA, it was necessary to be viewed whether the data of each factor was distributed normally. The result of Distribution Normality was presented in Table 4.

Table 4. Data DistributionNormality on Mathematical Communication Ability Based on Group and Prior Mathematical Ability

(The level of significance $\alpha=0.05$ )

\begin{tabular}{|c|c|c|c|c|}
\hline \multirow[b]{2}{*}{ Group } & \multirow[b]{2}{*}{ Ability } & \multicolumn{2}{|c|}{ DistributionNormality Test } & \multirow{2}{*}{$\begin{array}{c}\text { Implications of } \\
\text { The Use of Two Ways } \\
\text { ANOVA }\end{array}$} \\
\hline & & Sig. & Conclusion & \\
\hline Experiment & - & 0.006 & Not Normal & \multirow{5}{*}{$\begin{array}{c}\text { Two Ways ANOVA is not } \\
\text { used }\end{array}$} \\
\hline Control & - & 0.006 & Not Normal & \\
\hline- & Low & 0.163 & Normal & \\
\hline- & Middle & 0.072 & Normal & \\
\hline- & High & 0.022 & Not Normal & \\
\hline
\end{tabular}

From Table 4 it appeared that the condition for using Two Ways ANOVA was not sufficient. Therefore, the interaction effect was analyzed using Diagram 1 and Table 5.

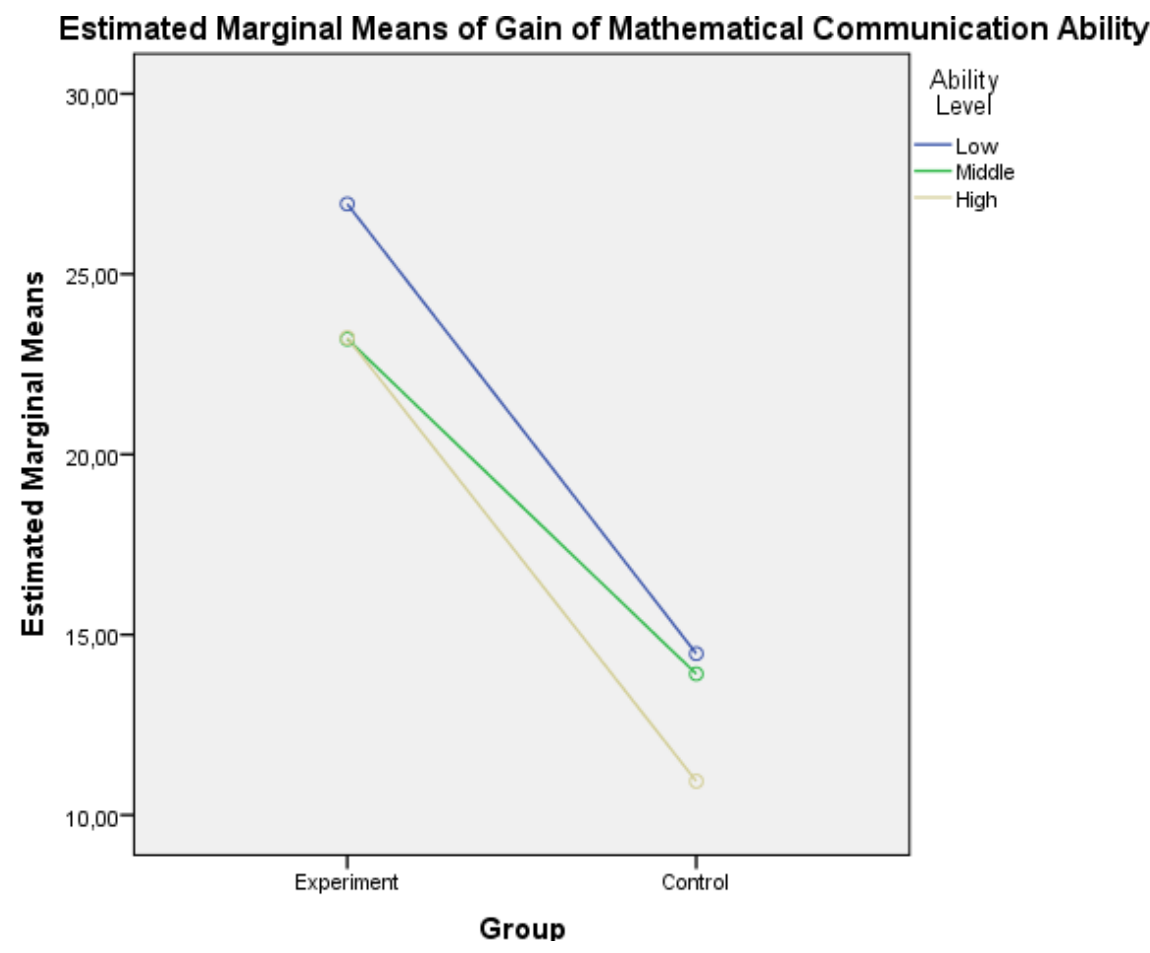

Diagram 1. Interaction Effect Teaching Approach and Prior Mathematical Ability on Enhancement of Students' Mathematical Communication Ability 
The Diagram 1 indicated that there was interaction effect between teaching approaches and prior mathematical ability toward enhancement of students' mathematical communication ability. To confirm the presence of this interaction effect is significant, it was necessary to be tested the difference of the gain among mathematical ability levels (low, midlle, and high), both in the experimental and the control groups, as presented in Table 5.

Table 5. Test of Difference of Mathematical Communication Ability Gain (Gain of MCA) based on Ability Levels of Experimental and Control Groups

(The level of significance $\alpha=0.05$ )

\begin{tabular}{|c|c|c|c|c|}
\hline \multirow[b]{2}{*}{ Variable } & \multirow{2}{*}{$\begin{array}{c}\text { Ability } \\
\text { Level }\end{array}$} & \multicolumn{3}{|c|}{ Difference Test } \\
\hline & & $\begin{array}{c}\text { Statistic } \\
\text { Test }\end{array}$ & Sig. & Conclusion \\
\hline \multirow{3}{*}{$\begin{array}{c}\text { MCA Gain } \\
\text { of Experimental Group }\end{array}$} & Low & \multirow{3}{*}{$\begin{array}{l}\text { Kruskal- } \\
\text { Wallis }\end{array}$} & \multirow{3}{*}{0.332} & \multirow{3}{*}{$\begin{array}{c}\text { Not } \\
\text { Different }\end{array}$} \\
\hline & Middle & & & \\
\hline & High & & & \\
\hline \multirow{3}{*}{$\begin{array}{c}\text { MCA Gain } \\
\text { of Control Group }\end{array}$} & Low & \multirow{3}{*}{$\begin{array}{l}\text { Kruskal- } \\
\text { Wallis }\end{array}$} & \multirow{3}{*}{0.288} & \multirow{3}{*}{$\begin{array}{c}\text { Not } \\
\text { Different }\end{array}$} \\
\hline & Middle & & & \\
\hline & High & & & \\
\hline
\end{tabular}

From Table 5, it could be seen that there were no differences of enhancement of students' mathematical communication ability in experiment group among the low, midlle, and high level students. The same result was occured in the control group. It can be concluded that there is no significant interaction effect between teaching approaches and prior mathematical ability toward enhancement of students' mathematical communication ability.

\subsection{Discussion}

The results showed that the enhancement of communication ability of students who acquired teaching under metacognitive scaffolding approach is significantly higher than students who acquired teaching under direct approach. Thus, it could be said that teaching mathematics under metacognitive scaffolding approach significantly positive impact on enhancement of students' mathematical communication ability. Clark, Jacobs, Pittman, \& Borko (2005) stated that giving problems that triggered discussion was a strategy in developing mathematical communication. By giving mathematical problems, students in small groups tried to understand and showed the model of the problem solution, and the solving models developed students would be object of discussion, or revision of the understanding of mathematical problem faced. It appeared students in some groups argued for their opinion, while in other group it appeared that a student explained his idea to friends in his group. Thus, through cooperative learning, students not only got an understanding of mathematical solving, but they also had opportunity to represented and evaluated mathematical ideas to be tested and compared it with the mathematical idea of their friend. Teacher encouraged students to actively engaged in discussions, and provided assistance if there was a group of students came to a halt in understanding or solving the problem. The presence of these metacognitive questions encouraged students to identify the problem, identify relevant information, display ideas, and explain mathematical ideas to the friends group. The findings of this study were consistent with there commendation 
Clark et al. (2005) which stated that teachers should encourage students to actively explain the mathematical ideas.

Although it was not as high as in teaching under metacognitive scaffolding approach, there was a significant enhancement of mathematical communication ability of students who obtained teaching under direct approach. Teaching under this approach is characterized by teacher activities, such as explain a concept. When the teacher explains a concept, students gain an understanding of the concept needed to build mathematical communication ability. New knowledge acquired by students encourage them to match the existing cognitive structure and frequently it was preceded by cognitive conflict (disequilibrium); furthermore through student's question and teacher's answer, this conflict can be resolved, so that the cognitive structures remain in equilibrium. It encouraged the development of thinking and understanding of concepts, which is required to solve mathematical problems, especially with problems related to mathematical communication ability.

The presence of solving mathematical problem samples by teacher could encourage students learned meaningfully, because those samples based on the concepts that was already explained by their teacher and understood by the students could be used as a model completion by students in solving mathematical problems, especially those related to mathematical communication ability. In addition, the time required on teaching under direct approach was efficient, so that teachers can provide additional practice materials. The presence of the materials made students had chance to practice more and represent mathematical ideas in a variety of forms, so that adds to the experience in the face of problems related to mathematical communication. According to Pressley (1995), with experiences, gradually students were able to implement relevant strategies flexibly and precisely. Although the samples of solving mathematical problems could encourage mathematical communication ability, it could also lead students tend to imitate those procedures. As a result, students solved the problems easily if the problems were similar to the samples, but he had trouble when facing new problems. Furthermore, in learning the direct approach, there is avery limited social interaction, almost nothing, especially the interaction among students. Meanwhile, Vygotsky (1980) considers that an individual's cognitive development depends on social interaction. Therefore, it could be predicted that the presence of mathematical problems, metacognitive questions and cooperative learning on teaching under metacognitive scaffolding approach on the one hand, and the explanation of the concepts and samples of solving mathematical problems on teaching under direct approach on the other hand, are factors that could explain one of the results of this study, enhancement of students' mathematical communication ability who acquired teaching under metacognitive scaffolding approach was higher than students who acquired teaching under direct approach.

Data analysis showed that there was no interaction effect between learning approaches (scaffolding metacognitive and the direct) and students' prior mathematical ability (high, midlle, and low) toward the enhancement of students' mathematical communication. In teaching under metacognitive scaffolding approach, a teacher posed metacognitive questions when students had difficulty on understanding or solving the problem. The questions posed would be used by high ability students to link the mathematical problems encountered with mathematical ideas that will be displayed. This supported the study of Clark et al. (2005) argued that the posing of a problem was strategy that could develop students' mathematical communication. Besides that, there were elements of cooperative learning, that enable high ability students explained their mathematical ideas to friends in the group. 
The result of this study also showed that there was a significant enhancement of student mathematical communication ability for low and midlle ability students who obtained teaching under metacognitive scaffolding approach. On teaching under this approach, low and midlle ability students had been supported by high ability students. The support was obtained through discussions, explanations, and examples of mathematical representation. The interesting finding in this study was that the low and midlle ability students who obtained teaching under metacognitive scaffolding approach got benefit as much as high ability students who obtained teaching under the same approach. This finding could also be interpreted in the context of the theory of Piaget and Vygotsky. In terms of the theory of cognitive development (Piaget, 1970), metacognitive scaffolding approach played an important role in improving the cognitive development of low ability students. Cognitive conflicts on high ability students might be initiated by teacher's metacognitive questions that impacted on tension on the students and that gave a mismatch between what had been understood and the fact that be faced. It result an disequilibrium condition in the cognitive system then they tried to overcome it through thinking. In this case, the approach encouraged high ability students to overcome the disequilibrium condition by relying on their knowledge and experiences. For low and midlle ability students, cognitive conflicts may be acurated because of the cooperative learning with high student. In cooperative learning, low and midlle ability students were faced with a mathematical representation from high ability student. The mathematical representation as often not in accordance with the ideas developed by the low and midlle ability students. To resolve this conflict, they could ask for an explanation from the high ability students, so that a balance in their cognitive system was recovered (re-equilibrium). In teaching under metacognitive scaffolding approach, low and midlle ability students did not feel awkward discussed and applied their mathematical ideas to his friends, including to the high ability students. Effort of low and midlle ability students gave their argumentations were encouraged activate their prior knowledge with new mathematical problems. Thus, the discussion could activate of their schemata, so that allow the students elaborate and provide representation of the problem and the solution, either in the form of drawing, diagrams, as well as mathematical sentences.

The idea of a cooperative learning approach in teaching under metacognitive scaffolding approach related to zone of proximal development (ZPD) of Vygotsky (1980). Through cooperative learning with students obtained model of representation and solving problems from the high ability students, so that the low and midlle ability students were being able to achieve the level of mathematical communication that cannot be achieved without the metacognitive scaffolding approach. Thus, the approach gave low and midlle ability students could fully explore their potential capabilities, thus changing the position of the level of potential development into level of actual development, and the level of potential development moving into his new position. It could be predicted that the enhancement of mathematical communication ability of high ability students who obtained teaching under metacognitive scaffolding approach triggered by readiness of their mathematical knowledge and metacognitive assistance from their teacher, while the low and midlle ability students were triggered by the interaction with high ability students.

In teaching under direct approach, high ability students showed an enhancement of their mathematical communication ability. This enhancement seemed to be related to their readiness of mathematical knowledge and learning experiences. In addition, this enhancement was apparently due to an explanation of mathematical concept and representation of solving problems. Explanation of mathematical concepts through illustrations that were easy to be understood and providing representation of solving problems step by step, would give a positive effect on mathematical communication of 
high ability students. If in the metacognitive scaffolding approach, there was an aspect of metacognitive assistance, then in the direct approach, there were aspects of a concept explanation and an example of representation of solving a problem. Thus it was predicted that the metacognitive assistance on teaching under metacognitive scaffolding approach on the one hand, and the readiness of a concept explanation and the example on solving a problem on teaching under direct approach on the other hand were factors that could explain one of the results of this study, which was no difference of enhancement of mathematical communication ability between high ability students who obtained teaching under metacognitive scaffolding approach and those who obtained teaching under direct approach. This evidence suggested that teaching by applying principles of constructivism was not always better compared to teaching by applying principles of behaviorism. Conversely, teaching by applying principles of behaviorism is not always worse compared to teaching by applying principles of constructivism.

For low and midlle ability students who obtained teaching under direct approach, the research result showed that there was a significant enhancement of students' mathematical communication ability. Explanation of mathematical concepts through illustrations that were easy to be understood and providing representation of solving problems step by step, would give a positive effect on mathematical communication. Explanation of the concept and representation of solving problem were suspected as factors indetermining the enhancement of mathematical communication of low and midlle students that obtained teaching under direct approach. However, although apparently students might understood only on the specific problems. Therefore, it could be indicated that the presence of cooperative learning in teaching under metacognitive scaffolding approach on the one hand, and the explanation of concepts and the examples of representation of solving problems on the other hand are factors that could explain one of the results of this study, that was the enhancement of mathematical communication ability of low and midlle ability students who obtained teaching under metacognitive scaffolding approach higher than those who obtained teaching under direct approach.

\section{CONCLUSION}

Based on the results of the study, the conclusions are there is a difference in mathematical communication ability between students under metacognitive scaffolding teaching approach and students under direct teaching approach. The enhancing in mathematical communication ability of students under metacognitive scaffolding teaching approach higher students under direct teaching approach. Furthermore, there is no interaction effect learning approaches and prior mathematical skills on the enhancement of students' mathematical communication.

These study results are only based on specific aspects of mathematical ability, the subject is limited, and the topic is narrowed. Even so, it is clear that the approach was effective in supporting students' mathematical communication ability. In addition, the implementation of learning with metacognitive scaffolding approach did not require expensive. Therefore, the recommedation is that the teaching under metacognitive scaffolding approach can be tried in other aspects of mathematical ability, other topics or other subject matter. 


\section{REFERENCES}

Carpenter, J \& Gorg, S, (2000), Principles and standards for school mathematics. Reston, VA: National Council of Teachers of Mathematics.

Clark, K. K., Jacobs, J., Pittman, M. E., \& Borko, H. (2005). Strategies for building mathematical communication in the middle school classroom: Modeled in professional development, implemented in the classroom. Current Issues in Middle Level Education, 11(2), 1-12.

Departemen Pendidikan Nasional RI (2006). Peraturan Menteri Pendidikan Nasional Republik Indonesia Nomor 22 Tahun 2006 tentang Standar Isi untuk Satuan Pendidikan Dasar dan Menengah. Lampiran 3: Standar Kompetensi dan Kompetensi Dasar Mata Pelajaran Matematika untuk SMA/MA.

Hecox, C. C. (2010). Cooperative learning and the gifted student in elementary mathematics. $\quad$ Retrieved March 9, 2012 from https://digitalcommons.liberty.edu/cgi/viewcontent.cgi?referer=https://scholar.goog le.com $/ \&$ httpsredir $=1 \&$ article $=1385 \&$ context=doctoral

Hill, H. C., Rowan, B., \& Ball, D. L. (2005). Effects of teachers' mathematical knowledge for teaching on student achievement. American educational research journal, 42(2), 371-406.

Iqbal, M. (2004). Effect of cooperative learning on academic achievement of secondary school students in mathematics (Doctoral dissertation, University Of Arid Agriculture).

Mullis, I. V., Martin, M. O., Gonzalez, E. J., \& Chrostowski, S. J. (2004). TIMSS 2003 International Mathematics Report: Findings from IEA's Trends in International Mathematics and Science Study at the Fourth and Eighth Grades. TIMSS \& PIRLS International Study Center. Boston College, 140 Commonwealth Avenue, Chestnut Hill, MA 02467.

OECD. (2005). PISA 2003 Technical Report. Retrieved April 25, 2012, from http://www.oecd.org/education/school/programmeforinternationalstudentassessmen tpisa/35188570.pdf

OECD. (2007). PISA 2006 results. Retrieved April 25, 2012, from https://www.oecd.org/education/school/programmeforinternationalstudentassessme ntpisa/pisa2006results.htm

OECD. (2010). PISA 2009 Results: Executive Summary. Retrieved April 25, 2012, from https://www.oecd.org/pisa/pisaproducts/46619703.pdf

Passos, A. F. J. (2009). A comparative analysis of teacher competence and its effect on pupil performance in upper primary schools in Mozambique and other SACMEQ countries (Doctoral dissertation, University of Pretoria).

Peters, G. (2011). Advantages \& Disadvantages of Scaffolding in the Classroom. Retrieved April 25, 2012, from https://www.theclassroom.com/advantages-disadvantagesscaffolding-classroom-8008434.html

Piaget, J. (1970). Science of education and the psychology of the child. Trans. D. Coltman.

Pressley, M. (1995). More about the development of self-regulation: Complex, long-term, and thoroughly social. Educational psychologist, 30(4), 207-212. 
Vygotsky, L. S. (1980). Mind in society: The development of higher psychological processes. Harvard university press.

Yee, F.P. (2002). Using Short Open-ended Mathematics Questions to Promote Thinking and Understanding, Singapore: National Institute of Education. 